\title{
Antimicrobial Activities of Some Plants from Ivorian Flora on Southern Blight in Côte d'ivoire
}

\author{
N'guessan Aya Carine ${ }^{1}$, Amari Ler-N’Ogn Dadé Georges Elisée ${ }^{2}$, Johnson Félicia ${ }^{3}$ and Koné Daouda ${ }^{2,4}$ \\ 1. Département de Biologie végétale, UFR Sciences Biologiques, Université Peleforo Gon Coulibaly Korhogo, Côte d'Ivoire \\ 2. Laboratoire de Physiologie végétale, UFR Biosciences, Université Félix Houphouët-Boigny Cocody-Abidjan, Côte d'Ivoire \\ 3. Laboratoire de Zoologie et Biologie Animale, UFR Biosciences, Université Félix Houphouët-Boigny Cocody-Abidjan, Côte \\ d'Ivoire \\ 4. Centre d'excellence sur les changemants climatiques la biodiversité et l'agriculture durable (CEA-CCBAD)
}

\begin{abstract}
This study aims at determining and comparing the in vitro antifungal activity of six EOs (essential oils) extracted from Monodora myristica, Melaleuca quinquenervia, Eucalyptus torelliana, Chenopodium ambrosioides, fresh Zingiber officinalis and dehydrated Zingiber officinalis with those of three synthetic fungicides (Callicuivre, Banko plus and Mancozeb) on Sclerotium rolfsii a pathogenic fungus of tomato in Côte d'Ivoire. The products were added to PDA (potato dextrose agar) medium at various concentrations. The results showed different aspects of the mycelium, different activities on mycelium growth and sclerotia production depending on the explants (mycelium or sclerotia). Depending on their IC and MGI (mycelium growth inhibition), the oils stemming from Chenopodium ambrosioides and fresh Zingiber officinalis showed more inhibitory activities on mycelial growth (reduction rate of 100\%) and sclerotia production at $250 \mathrm{ppm}$. These activities were close to or even greater than those of fungicides. The mancozeb fungicide showed stronger activity than the others by inhibiting mycelium growth and sclerotia production of mycelium explants at $250 \mathrm{ppm}$. This study offers the possibility of using EOs in the control strategies of Sclerotium rolfsii.
\end{abstract}

Key words: Solanum lycopersicon, Sclerotium rolfsii, sensitivity, synthetic fungicides, EOs.

\section{Introduction}

Tomato represents the third largest vegetable in the world after potato and sweet potato. Its world production in 2014 was estimated at 170 million tons. Tomato is used both in food and medicine. The fruits are eaten fresh or intended for processing. It is eaten in the form of juice, in concentrated form and as raw vegetable. The therapeutic virtues of tomato are found in all the functions involved in the defense metabolism of the organism. Tomato contains a set of antioxidants which limit damage to lipids, proteins and genetic material. These are tocopherols (vitamin E), carotenoids, vitamin $\mathrm{C}$ and polyphenols. These compounds are all found in tomato either in the skin

Corresponding author: Koné Daouda, CEA-CCBAD, full professor, research field: plant pathology. or pericarp, in the pulp (vitamin C) or in the seeds (tocopherols) [1,2].

Despite the importance of tomato, its yield is facing many problems especially with the proliferation of the different species of parasites and their distinctive features. Indeed, more than 200 diseases have been described on tomato overall. These diseases can be located in leaflets, roots, collars and other parts of the stem [3] and are caused by fungi, bacteria, viruses, nematodes etc. Among the parasitic fungi, Sclerotium rolfsii Sacc., a soil borne pathogen is an important parasite for tomatoes. The fungus can survive at $-10{ }^{\circ} \mathrm{C}$. It causes, by its white mycelium and its sclerotia, a dry rot at the level of the collar. The collar thickens, resulting in a wilting of the leaves which dry out, consequently cause significant economic losses. Southern rust is a common name for the disease 
caused by Sclerotium rolfsii. This disease was considered as a problem only in regions with warm climates. It is also called the Southern Burn because of the inability of the fungus to survive in severe winter conditions. The first report on this fungus dates back to 1892 with Peter d'Henry Rolfs on the rust of tomato in Florida [4]. The highest losses caused by Sclerotium rolfsii are recorded in groundnut. To this end, in 1959, the United States Department of Agriculture estimated losses of $\$ 10$ million to $\$ 20$ million related to this fungus in North Carolina [5]. Sclerotium rolfsii attacks primarily the stems of host plants, although it can infect any part thereof. The first signs of infection although usually undetectable are dark brown lesions on the stem or at the collar. The first obvious symptoms are wilting of the foliage, which dries out and turns brown as in the case of nematode attack. However, the presence of the fungus through the accumulation of sclerotia at the base of diseased plants and the production of white mycelium on infected tissues makes it possible to establish the diagnosis [6].

The use of synthetic fungicides is the most widely used method for controlling fungi, including Sclerotium rolfsii. However, the consequences for humans and their environment, the phenomenon of resistance of fungal strains and the scarcity and high cost of good quality products in local markets could lead to finding alternative solutions.

Resorting to medicinal plants through the use of easily applied plant extracts such as EOs (essential oils) is a low-cost solution with a lower impact on the environment and the consumer.

EOs are mixtures of aromatic substances. They are liquid, light and volatile. They are obtained through various physical processes such as steam distillation, solvent extraction [7, 8]. EOs are used at extremely low doses in various fields. The role of some of them has been experimentally established in the field of pathogenic host interactions.

EOs that have already been studied in phytochemical and biological studies have shown fungicidal, bactericidal, acaricidal and insecticidal properties [9, $10]$.

This study has been conducted in order to evaluate alternative control methods by comparing the effectiveness of EOs with synthetic fungicides on Sclerotium rolfsii.

\section{Material and Methods}

\subsection{Material}

The plant material consisted of diseased tomato plants identified on the vegetable plots at Songon-Dabou (Southern Côte d'Ivoire) on which mature sclerotia were harvested.

The fungal material was Sclerotium rolfsii.

Three fungicides were used in the experiment (Table 1). Six EOs were used at different concentrations. These oils were extracted from 5 plants: Monodora myristica, Melaleuca quinquenervia, Chenopodium ambrozioides, Eucalyptus torelliana and Zingiber officinalis. Two types of oils were obtained from Zingiber officinalis: from fresh ginger (Zingiber officinalis) and dehydrated ginger (Zingiber officinalis). For the others plants, the oils were obtained from fresh leaves.

The oils were supplied by the Structural Organic Chemistry Laboratory of the University Félix Houphouët Boigny (Côte d'Ivoire). They were extracted by the hydrodistillation technique [11].

Table 1 Active ingredients and concentrations of synthetic fungicides used.

\begin{tabular}{lll}
\hline Trade name & Active ingredient $(\mathrm{m} . \mathrm{a})$ & Recommended amount $(\mathrm{g} / \mathrm{L})$ \\
\hline Callicuivre & Copper Oxide & 5 \\
Mancozeb & Manebe $(80 \%)$ & 5 \\
Banko plus & Chlorothalonil + Carbendazime & 650 \\
\hline
\end{tabular}




\subsection{Methods}

\subsubsection{Obtention of Fungus Culture}

The experiment was conducted using two types of explants, mycelium and sclerotia of the fungus. The mycelium was obtained from a 7-day sclerotia culture provided from Songon plots on PDA (potato dextrose agar) medium. Sclerotia were produced from 7-day fungal colonies.

2.2.2 Preparation of the Different Concentrations of EOs and Fungicides

Essential oils and fungicides were tested at concentrations of 250,500,1,000,2,000, 4,000 and $6,000 \mathrm{ppm}$. These various concentrations were obtained by directly incorporating the product into the PDA culture medium previously sterilized at $121{ }^{\circ} \mathrm{C}$ under a pressure of 1 bar for $20 \mathrm{~min}$. After addition of the oil or fungicide, the medium was homogenized by magnetic stirring.

For the fungicides, the different concentrations were obtained according to the recommended dose of each product. These synthetic fungicides were used as positive controls.

Negative controls consisted of media containing no concentration of $\mathrm{EO}$ and fungicide. The homogenized media were distributed into 9-cm diameter petri dishes. For each concentration, 5 Petri dishes were used.

\subsubsection{Seeding of Media Culture}

In this experiment, the mycelium was removed using a 6-mm diameter explant. The sample explant (mycelium and sclerotia) was placed in the center of the Petri dishes. These dishes were placed in incubation room under a photoperiod of 12 hours at a temperature of $27-2{ }^{\circ} \mathrm{C}$.

2.2.4 Evaluation of Mycelial Growth and Sclerotia Production

The effect of the different concentrations of oils and fungicides on mycelial growth was measured and the numbers of sclerotia produced were estimated. Also, the appearance of mycelium was described.
Mycelial growth was measured every 24 hours by measuring the average of two perpendicular diameters drawn under the box and passing through the middle of the explant.

These radial growth measurements made it possible to calculate the different MGI (mycelium growth inhibition) percentage by the following formula:

$$
\text { MGI }=\left(X_{t}-X_{e}\right) / X_{t} \times 100
$$

where $X_{t}$ : the average growth of the fungus obtained from the negative controls (without oil or fungicide) and $\mathrm{X}_{\mathrm{e}}$ : the average growth of the fungus obtained from the tests (oil or fungicide).

The sclerotia count was performed every 5 days for 40 days. It consisted in harvesting and then counting the mature sclerotia (brown color).

\subsubsection{Statistical Analysis}

STATISTICA 7.1 software was used for statistical analysis. The Newman-Keuls hypothesis of ANOVA I at 5\% threshold was used to compare the MGI percentage for the concentrations of each product, the EOs and fungicides and the average number of sclerotia on the 40th day of fungus culture in the tests with respect to the control.

The antifungal activity was expressed from the concentration inhibiting by $50 \%$ and $90 \%$ ( $\mathrm{IC}_{50}$ and $\left.\mathrm{IC}_{90}\right)$ of parasite growth. $\mathrm{IC}_{50}$ and $\mathrm{IC}_{90}$ were determined from the equations of dose-response curves of concentrations of EOs tested [12].

\section{Results}

\subsection{Effect of EOs and Fungicides on Mycelia Aspect}

The fungus growth on different media containing oils and fungicides has been affected (Fig. 1). Thus, we distinguish several aspects:

- The fungus with medium abundant aerial mycelium and a uniform and sharp growth front (A);

- Inhibited explant and sclerotia (B);

- The palmate facies thallus (C);

- The feathered facies thallus ending in white duvets (D); 


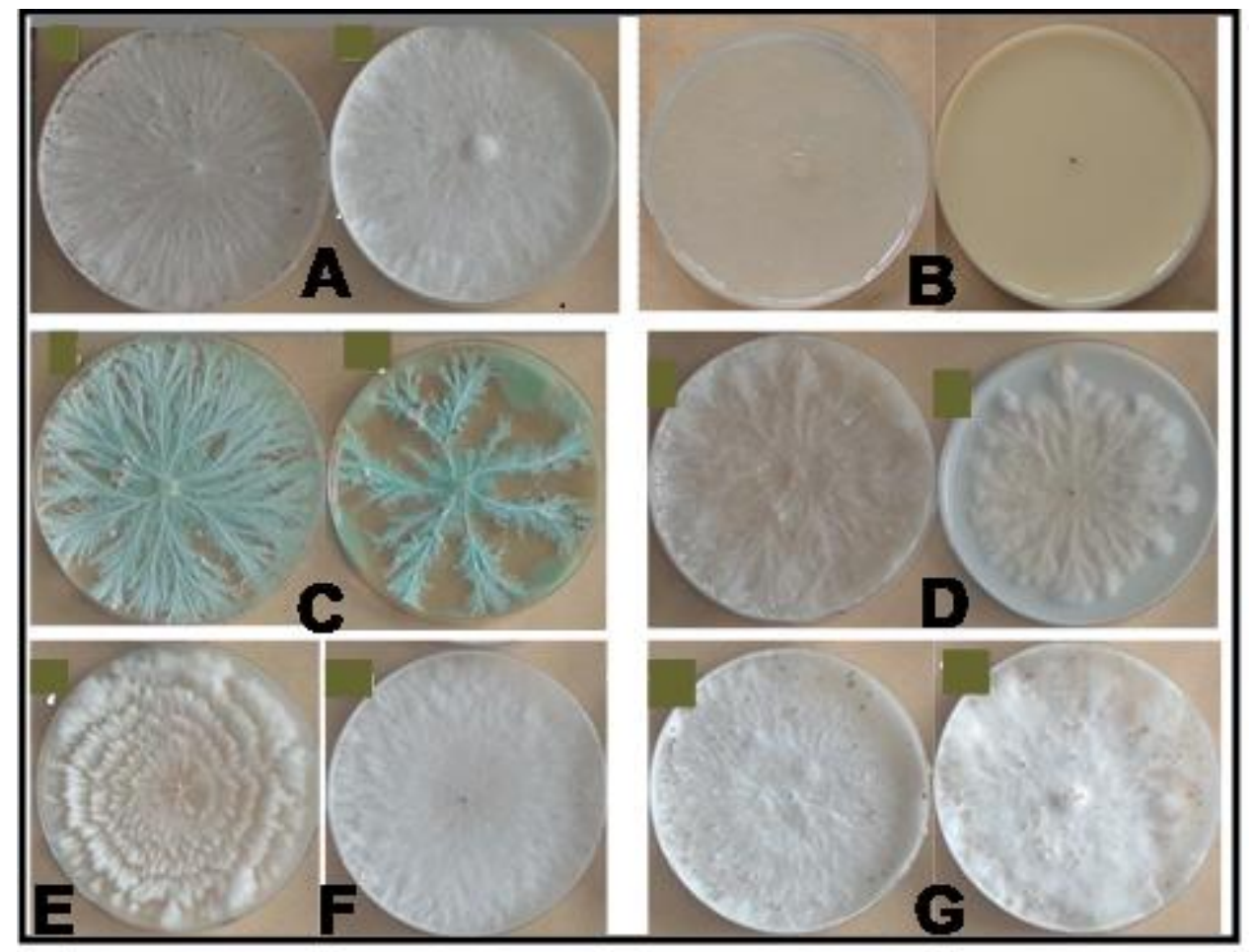

Fig. 1 Aspects of Sclerotium rolfsii colonies after 5 to 10 days on PDA media without product and supplementing with different concentrations of EOs and synthetic fungicides.

A: control, radial facies thalassemia, B: explants and inhibited sclerotia, C: palmated facies thallus, D: feathered facies thallus, E: lobed facies thallus, F: thallus with striated ragged facies, G: thallus with cottony facies.

- The lobed facies thallus appearing in a bristling form with concentric circles (E);

- The striped facies thallus (F);

- The cottony facies thallus $(\mathrm{G})$.

\subsection{Antifungal Activity of EOs}

The mycelial growth inhibition values are presented in Table 2. According to the results reported in Table 2, the fresh Zinziber officinalis was the most effective EO on S. rolfsii (explants from mycelia and sclerotia) because it caused $100 \%$ growth inhibition at all concentrations tested. However, mancozeb fungicides were more effective on mycelia explants at all concentrations, however it was effective on sclerotia at 6,000 ppm. Also the minimum activity was recorded for Monodora myristica and Eucalyptus torrelianna EOs (MGI $=0 \%$ ) even at 6,000 ppm, inhibition of the mycelium was observed. These 2 EOs activities were comparable to callicuivre fungicide.

By increasing the oil concentration from 250 to $6,000 \mathrm{ppm}$, the antifungal activity of Melaleuca quinquenervia and dehydrated Zinziber officinalis EOs were substantially increased. Melaleuca quinquenervia and Dehydrated Zinziber officinalis EOs at 6,000 ppm and 1,000 ppm concentration respectively showed complete antifungal activity (100\%) while other concentrations of Melaleuca quinquenervia (2,000 ppm) for explants obtained by mycelium and (1,000 and 2,000 ppm) for explants obtained by sclerotia prevented $S$. Rolfsii growth, with MGI values of $1.55 \%$ and $57.89 \%$ and $75.33 \%$ respectively.

Chenopodium ambrosoïdes EO showed total inhibition (MGI $=100 \%)$ at the concentration of 2,000 ppm as well as Banko Plus fungicide on the mycelium explant. As for sclerotia explant, total inhibition was observed at $500 \mathrm{ppm}$. 
Table 2 Antifungal activity of EOs and fungicides against Sclerotium rolfsii.

\begin{tabular}{|c|c|c|c|c|c|c|c|c|c|c|}
\hline \multirow[b]{2}{*}{$\begin{array}{l}\text { Type of } \\
\text { explant }\end{array}$} & \multirow[b]{2}{*}{$\begin{array}{l}\text { Concentration } \\
(\mathrm{ppm})\end{array}$} & \multicolumn{6}{|c|}{ MGI percentage per EO } & \multicolumn{3}{|c|}{$\begin{array}{l}\text { MGI percentage per } \\
\text { Fungicide }\end{array}$} \\
\hline & & $\begin{array}{l}\text { Monodora } \\
\text { myristica }\end{array}$ & $\begin{array}{l}\text { Melaleuca } \\
\text { quinquenervia }\end{array}$ & $\begin{array}{l}\text { Eucalyptus } \\
\text { torrelianna }\end{array}$ & $\begin{array}{l}\text { Chenopodium } \\
\text { ambrosoüdes }\end{array}$ & $\begin{array}{l}\text { Dehydrated } \\
\text { Zinziber } \\
\text { officinalis }\end{array}$ & $\begin{array}{l}\text { Fresh } \\
\text { Zinziber } \\
\text { officinalis }\end{array}$ & Callicuivre & $\begin{array}{l}\text { Banko } \\
\text { Plus }\end{array}$ & Mancozeb \\
\hline \multirow{6}{*}{ Mycelium } & 250 & $0 \mathrm{a}$ & $0 \mathrm{a}$ & $0 \mathrm{a}$ & $75.60 \mathrm{e}$ & $0 \mathrm{a}$ & $100 \mathrm{~g}$ & $0 \mathrm{a}$ & $0 \mathrm{a}$ & $100 \mathrm{fg}$ \\
\hline & 500 & $0 \mathrm{a}$ & $0 \mathrm{a}$ & $0 \mathrm{a}$ & $77.86 \mathrm{e}$ & $0 \mathrm{a}$ & $100 \mathrm{~g}$ & $0 \mathrm{a}$ & $0 \mathrm{a}$ & $100 \mathrm{fg}$ \\
\hline & 1,000 & $0 \mathrm{a}$ & $0 \mathrm{a}$ & $0 \mathrm{a}$ & 83.69 ef & $100 \mathrm{~g}$ & $100 \mathrm{~g}$ & $0 \mathrm{a}$ & $\begin{array}{l}25.83 \\
\mathrm{bc}\end{array}$ & $100 \mathrm{fg}$ \\
\hline & 2,000 & $0 \mathrm{a}$ & $1.55 \mathrm{a}$ & $0 \mathrm{a}$ & $100 \mathrm{~g}$ & $100 \mathrm{~g}$ & $100 \mathrm{~g}$ & $0 \mathrm{a}$ & $100 \mathrm{fg}$ & $100 \mathrm{fg}$ \\
\hline & 4,000 & $0 \mathrm{a}$ & $99.40 \mathrm{~g}$ & $0 \mathrm{a}$ & $100 \mathrm{~g}$ & $100 \mathrm{~g}$ & $100 \mathrm{~g}$ & $0 \mathrm{a}$ & $100 \mathrm{fg}$ & $100 \mathrm{fg}$ \\
\hline & 6,000 & $0 \mathrm{a}$ & $100 \mathrm{~g}$ & $2.5 \mathrm{a}$ & $100 \mathrm{~g}$ & $100 \mathrm{~g}$ & $100 \mathrm{~g}$ & $0 \mathrm{a}$ & $100 \mathrm{fg}$ & $100 \mathrm{fg}$ \\
\hline \multirow{6}{*}{ Sclerotia } & 250 & $0 \mathrm{a}$ & $0 \mathrm{a}$ & $0 \mathrm{a}$ & $97.11 \mathrm{~g}$ & $0 \mathrm{a}$ & $100 \mathrm{fg}$ & $0 \mathrm{a}$ & $0 \mathrm{a}$ & $0 \mathrm{a}$ \\
\hline & 500 & $0 \mathrm{a}$ & $0 \mathrm{a}$ & $0 \mathrm{a}$ & $100 \mathrm{~g}$ & $0 \mathrm{a}$ & $100 \mathrm{fg}$ & $0 \mathrm{a}$ & $0 \mathrm{a}$ & $26.22 \mathrm{bc}$ \\
\hline & 1,000 & $0 \mathrm{a}$ & $75.33 \mathrm{e}$ & $0 \mathrm{a}$ & $100 \mathrm{~g}$ & $100 \mathrm{~g}$ & $100 \mathrm{fg}$ & $0 \mathrm{a}$ & $0 \mathrm{a}$ & $71.67 \mathrm{e}$ \\
\hline & 2,000 & $0 \mathrm{a}$ & $57.89 \mathrm{~d}$ & $0 \mathrm{a}$ & $100 \mathrm{~g}$ & $100 \mathrm{~g}$ & $100 \mathrm{fg}$ & $0 \mathrm{a}$ & $\begin{array}{l}32.11 \\
\mathrm{bc}\end{array}$ & $89.78 \mathrm{fg}$ \\
\hline & 4,000 & $0 \mathrm{a}$ & $97.11 \mathrm{~g}$ & $0 \mathrm{a}$ & $100 \mathrm{~g}$ & $100 \mathrm{~g}$ & $100 \mathrm{fg}$ & $0 \mathrm{a}$ & $\begin{array}{l}36.22 \\
\text { bc }\end{array}$ & $97.78 \mathrm{~g}$ \\
\hline & 6,000 & $20.67 \mathrm{~b}$ & $100 \mathrm{~g}$ & $4.78 \mathrm{a}$ & $100 \mathrm{~g}$ & $100 \mathrm{~g}$ & $100 \mathrm{fg}$ & $0 \mathrm{a}$ & $\begin{array}{l}32.89 \\
\mathrm{bc}\end{array}$ & $100 \mathrm{fg}$ \\
\hline
\end{tabular}

Averages within a column indicated by the same letter were not significantly different according to the Newman-Keuls tests at the level $p<0.05$.

Table $3 \mathrm{IC}_{50}$ and $\mathrm{IC}_{90}$ of EOs and fungicides at 9 days of culture of Sclerotium rolfsii.

\begin{tabular}{|c|c|c|c|c|c|}
\hline & & \multicolumn{2}{|c|}{$\mathrm{IC}_{50}$} & \multicolumn{2}{|c|}{$\mathrm{IC}_{90}$} \\
\hline & & Mycelium & Sclerotia & Mycelium & Sclerotia \\
\hline \multirow{6}{*}{ EOs } & Monodora myristica & - & $17,965.57$ & - & $31,432.40$ \\
\hline & Melaleuca quinquenervia & $3,080.15$ & $1,982.95$ & $4,990.72$ & $4,425.51$ \\
\hline & Eucalyptus torrelianna & $140,289.33$ & $73,946.89$ & $251,615.17$ & $132,198.78$ \\
\hline & Chemopodium ambrosoïdes & $10^{(-18,634.52)}$ & $10^{(-486,485)}$ & $2,405.80$ & $10^{(-485,205)}$ \\
\hline & Fresh Ginger & - & - & - & - \\
\hline & Dehydrated ginger & $1,169.84$ & $1,169.84$ & $3,862.23$ & $3,862.23$ \\
\hline \multirow{3}{*}{ Fungicides } & Callicuivre & - & - & - & - \\
\hline & Banko plus & $2,059.81$ & $7,190.96$ & $4,213.87$ & $13,106.26$ \\
\hline & Mancozeb & - & $1,304.28$ & - & $4,077.70$ \\
\hline
\end{tabular}

The comparison between tested EOs and fungicides was further confirmed by comparing their $\mathrm{IC}_{50}$ and $\mathrm{IC}_{90}$ values that are shown in Table 3. The types of explant showed variability in their reaction against the action of EOs and fungicides. $\mathrm{IC}_{50}$ and $\mathrm{IC}_{90}$ values for Eucalyptus and Monodora were higher than others. $S$. rolfsii resisted to the action of these Eos.

$\mathrm{IC}_{50}$ and $\mathrm{IC}_{90}$ of fresh ginger EO and Mancozeb fungicide (only for the mycelium explant) were not determined because there was no variation in the MGI $(100 \%)$. It was the same case for Monodora EO (for mycelium) and Callicuivre fungicide, however the MGI was $0 \%$.

\subsection{Effect of EOs and Fungicides on Sclerotia} Production

3.3.1 Effect of Different Treatments of EOs and Fungicides on the Sporulation of Sclerotium rolfsii Colonies Obtained from Mycelium 40 Days after Sowing

With the exception of fresh zingiber (total inhibition of sporulation), sclerotia production was observed in 
all oils depending on the concentration. The highest amounts of sclerotia (188 sclerotia) were recorded in Melaleula quinquenervia oils at $500 \mathrm{ppm}$ and Monodora myristica at 1,000 ppm. However, for the EOs of Chemopodium ambrosoides, dehydrated Zingiber and Melaleula quinquenervia, inhibition of sclerotia production was observed respectively from concentrations of 1,000 (for the first 2 oils) and 4,000 ppm (Fig. 2).

Concerning synthetic fungicides, total inhibition of sclerotia was observed at all concentrations for Maneb and from 2,000 ppm for Banko plus. With Callicuivre, sclerotia production was observed depending on the concentrations tested (Fig. 2).

3.3.2 Effect of Different Treatments of EOs and Fungicides on the Sporulation of Sclerotium rolfsii Colonies Obtained from Sclerotia 40 Days after Sowing

A total inhibition of sporulation was observed with the EO of fresh zingiber at all concentrations. With the oils of dehydrated Zingiber, Chemopodium ambrosoides, total inhibition of the production of sclerotia was recorded at $1,000 \mathrm{ppm}$ while for Melaleula quinquenervia it was observed from 4,000 $\mathrm{ppm}$. The highest production of sclerotia (about 200) was observed in the EO of Monodora myristica at a concentration of 2,000 ppm (Fig. 3).

Concerning synthetic fungicides, total inhibition of sclerotia was observed in Maneb from 2,000 ppm.

\section{Discussion}

The sensitivity of Sclerotium rolfsii to the EOs and fungicides tested revealed the parameters of mycelial growth, spore production and the appearance of the thallus. The products used had modified the phenotype of fungus colonies which took several aspects. These modifications resulted in formations or even the destruction of mycelial filaments at high concentrations. They can be explained by the reactions of the fungus in order to develop resistance mechanisms. These mechanisms could lead to damage to membranes, resulting in hyphal cell deterioration [13]. The fungus did not have the same sensitivity to EOs and fungicides. This showed that these products did not have the same active ingredients.

The oils of Eucalyptus torelliana, Monodora myristica and Melaleuca quinquenervia showed low antifungal activity at low concentrations. However, at concentrations of 4,000 and 6,000 ppm of Melaleuca quinquenervia and Monodora, this activity was high, exceeding $80 \%$ in the first two days before gradually decreasing. This may explain the weak interaction between the main components of Melaleuca quinquenervia (1.8 cineole, alpha pinene and viridiflorol), Eucalyptus torelliana and Monodora myristica, and those of the fungus. These results have also been reported by Nguefack et al. [14] on the sensitivity of Fusarium moniliforme and Aspergillus to Monodora myristica.

Fresh Gingiber officinallis oil was the best inhibitor of mycelial growth of Sclerotium rolfsii colonies in oils. The fact that ginger totally inhibits mycelial growth could be explained by its spicy character (burning and pungent flavor) is due to the presence of zingols, shogaols and especially zingiberene. Indeed, once incorporated into the culture medium, the oil stopped the development of fungal colonies. This would be in connection with these compounds which act to neutralize all mechanisms and processes involved in cell multiplication of the fungus. The presence of these compounds, in particular zingiberine, has been reported as an inducer of the resistance of tomato to a potato insect [15].

As regards the oil of dehydrated Zingiber officinalis, the inhibitory activity was observed above 500 ppm. This could be explained by the dilution effect which at low concentrations promotes the growth of the fungus. The results obtained with fresh ginger could be compared with those of Khanna et al. [16], which showed that the extracts of Ocimum gratissimum completely inhibited the growth of Sclerotium rolfsii at concentrations between 50 and $500 \mathrm{ppm}$ and those 


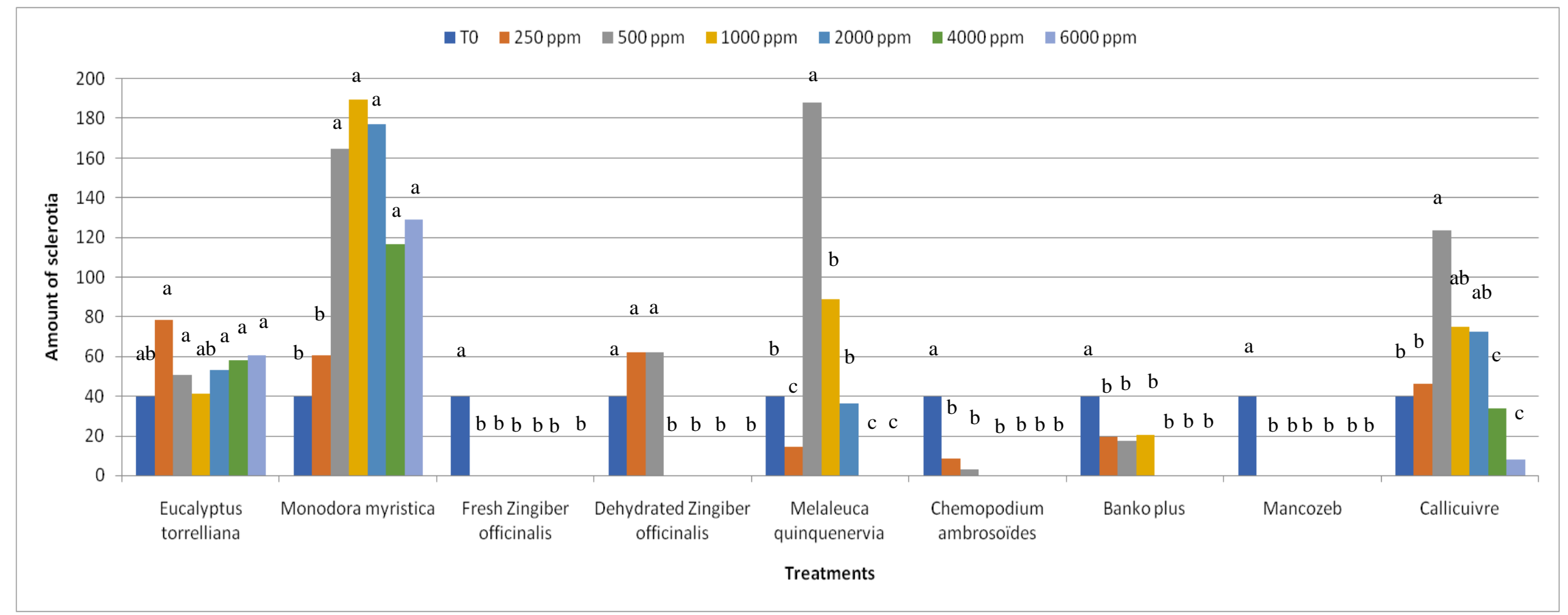

Fig. 2 Effect of fungicides and EOs on sclerotia produced by Sclerotium rolfsii obtained by the mycelium 40 after inoculation on amended media. 


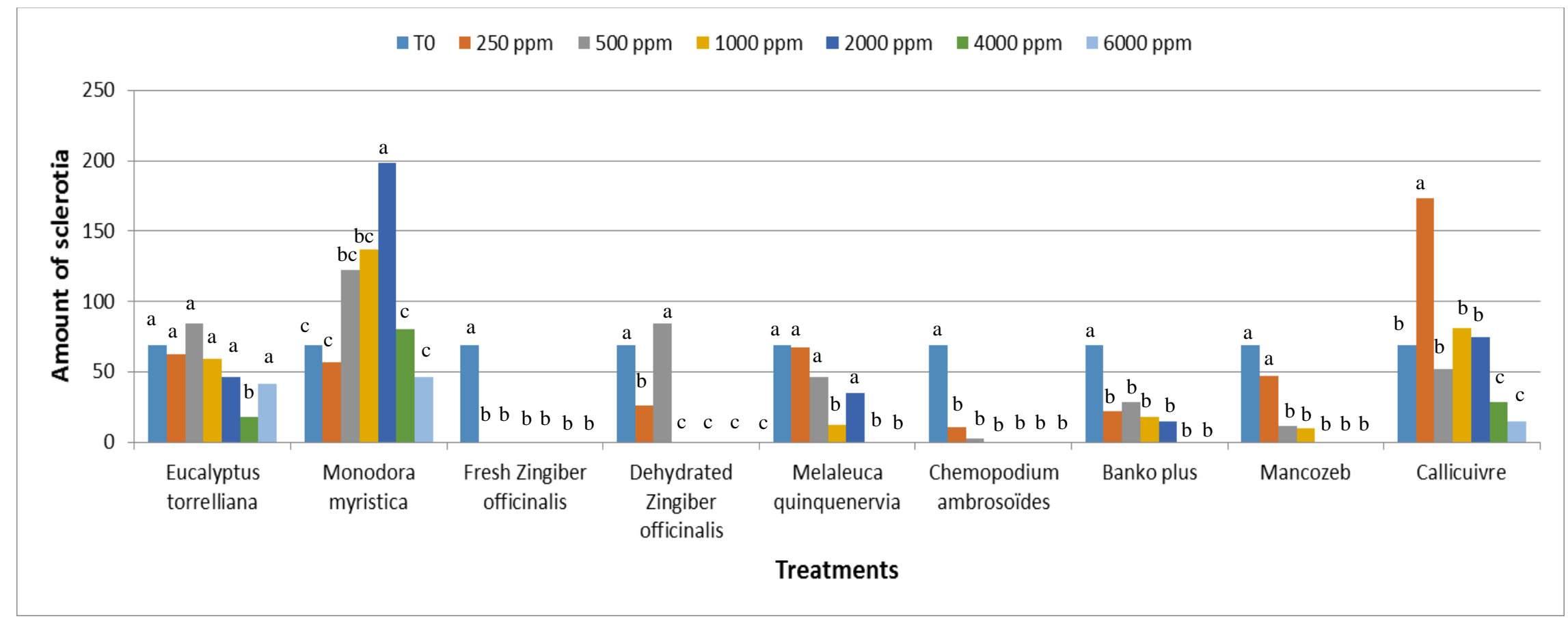

Fig. 3 Fungicidal activity of fungicides and EOs on sclerotia produced by Sclerotium rolfsii obtained by sclerotia 40 after inoculation on amended media. 
of Tewari and Najak [17] who also showed that the extracts of Ocimum sanctum inhibited the growth of 3 pathogens of rice. As regards the effect of fungicides, it can be noted that inhibition occurred according to the products.

Callicuivre showed low antifungal activity at all concentrations tested. The effect of Callicuivre on growth was not different from that of Eucalyptus and Monodora.

With Banko plus fungicide, in colonies obtained from sclerotia, all concentrations favored growth but at different expressions. On the other hand, with colonies obtained from explants, at concentrations of 250,500 and 1,000 ppm, we noticed fungus growth. Beyond these concentrations, its growth was inhibited. Indeed, carbendazim, the active substance of Banko plus a compound that acts on mitochondrial respiration and Chlorothalonil, acting on the synthesis of amino acids and thus at high doses, there will be blockage of respiration by inactivation of energy formation which is ATP, resulting therefore in a blockage of the proliferation of colonies. Banko plus was more effective than Callicuivre, therefore more effective than Melaleuca and Eucalyptus oils.

As for Mancozeb, total inhibition of explant colonies at all concentrations and growth of sclerotia colonies was observed. However, inhibition was noted at the concentration of $6,000 \mathrm{ppm}$. This could be related to the structure of the fungus. Indeed, at the level of the explant, all the components of the mycelium being directly on the medium, Mancozeb will easily exert its inhibitory action. On the other hand, at the level of sclerotia, the protective layer prevented Mancozeb from penetrating the structure not before 3 days. After 3 days, the fungus grew up. For this purpose, some authors have described 4 layers at the sclerotic wall. It is a thick skin, bark of thick cells, cortex of thin-walled cells and medulla containing filamentous hyphae. It is indeed the first 3 layers that would prevent sclerotium inhibition by Mancozeb and the EOs. The fungicidal activity of
Mancozeb is superior to that of other synthetic fungicides and Monodora and Eucalyptus oils. As for the oils of Chenopodium ambrosioides and fresh Zingiber, they showed activities superior to those of fungicides. However, the inhibitory activity of Mancozeb fungicide was lower than that of the EOs Chenopodium ambrosioides and Zingiber. This observation would indicate the level of efficacy of the substances constituting the EOs. These substances would have different activity sites than synthetic fungicides. Depending on their efficacy, the products used can be classified as follows:

- Synthetic fungicides: Callicuivre < Banko plus < Mancozeb,

- EOs: Eucalyptus $\approx$ Monodora < Melaleuca < dehydrated Zingiber officinalis < Chenopodium ambrosioides < Fresh Zingiber officinalis,

- All the products: Eucalyptus $\approx$ Monodora $\approx$ Callicuivre < Melaleuca < Banko plus < Mancozeb < Dehydrated Zingiber officinalis < Chenopodium ambrosioides $<$ Fresh Zingiber officinalis.

The different products tested have an effect on sporulation.

By testing the effect of the products on Day 40, it was observed that the number of sclerotia evolved with concentrations up to a peak before decreasing. Obtaining the peak could be explained by the increase in stress which imposes on the fungus a state of encystment. At high concentrations, there is a decrease in the number of sclerotia. This is because the EOs are volatile products or by a decrease in the effect of the active ingredient for fungicides over time.

As for fresh ginger EO, there was a total inhibition of sporulation. The amount of sclerotium depended on mycelial density. Zingiber inhibited the growth of colonies of Sclerotium rolfsii and therefore of sporulation. Thus, no resumption of growth of the fungus was carried out at the different concentrations of EOs or fungicide or there was stunted growth after seeding on PDA medium, thus showing that the 
synthetic oil or fungicide may act similarly on growth and sporulation.

\section{Conclusion}

This study has highlighted the differential behavior of EOs compared to fungicides. Their activities were lower, close to or even higher than those of fungicides tested. Because of these activities, EOs of Chemopodium ambrosoïdes and Zingiber officinalis could be used as an alternative solution in integrated biological control systems against Sclerotium rolfsii.

\section{References}

[1] Gerster, H. 1997. "The Potential Role of Lycopene for Human Health.” J. Am. College Nutr. 16: 109-26.

[2] Rao, A., and Agarwal, S. 2000. "Role of Antioxidant Lycopene in Cancer and Heart Disease." J. Am. College Nutr. 19: 563-9.

[3] Jones, J. B., Stall, R. E., and Zitter, T. A. 1993. Compendium of Tomato Diseases, 2nd edition. USA: The American Phytopathology Society.

[4] Aycok, R. 1966. "Stem Rot and Other Disease Caused by Sclerotium rolfsii.” N. C. Agr. Exp Stn Bul. 174: 202.

[5] Garren, K. H. 1959. "La putréfaction de tiges d'arachides et de sa commande.” Agr. Exp. Sta. Bull. 144.

[6] Declert, C. 1991. $2^{\mathrm{e}}$ forum des maraîchers Linzolo 31 mars $1990-1^{\text {er }}$ avril 1990, Orstom, fonds documentaire numéro 34683.

[7] Koumaglo, K. H., Akpagana, K., and Glitho, H. A. 1994. "Essential oil of Diplolophium africanum Turez." $J$. Essent. Oil Res. 6: 449-52.

[8] Ketoh, K. H. 1998. "Utilisation des huiles essentielles de quelques plantes aromatiques du Togo comme biopesticides dans la gestion des stades de développement de Callosobruchus maculatus F (Coleoptera : Bruchidae)." Thèse de Doctorat Univ. du Bénin Lomé-Togo, p. 136.
[9] Camara, B., Kone, D., Kanko, C., et al. 2007. "Activité antifongique des huiles essentielles de Ocimum gratissimum L., de Monodora myristica (Gaaertn) Dunal et de deux produits de synthèses (Impulse® et Folicur®) sur la croissance mycélienne et la production de spore in vitro de Deightoniella torulosa (Syd.)." Ellis Rev Ivoir Sci Technol 9: 187-201.

[10] Pamo, T. E., Tapondjou, L., Tendonkeng, F., et al. 2003. "Effet des huiles essentielles des feuilles et des extrémités fleuries de Cupressus lusitanica sur la tique (Rhipicephalus lunulatus) à l'Ouest-Cameroun." Rev. Acad. Sci. Cameroun 3 (3): 169-75.

[11] Coffi, K., Koukoua, G., and N'Guessan, T. 1999. "Composition and Intraspecific Variability of the Leaf Oil of Lippia multiflora Mold from Ivory Coast." $J$. Essent. Oil Res. 11: 153-8.

[12] Kumar, V., Mathela, C. S., Tewari, G., Darshan, S., Tewari, A. K., and Bisht, K. S. 2014. "Chemical Composition and Antifungal Activity of Essential Oils from Three Himalayan Erigeron Species." LWT-Food Science and Technology 56: 278-83.

[13] Neri, F., Mari, M., and Brigati, S. 2006. "Control of Penicillium expansum by Plant Volatile Compounds." Plant Pathol. 55: 100-5.

[14] Nguefack, J., Leth, V., Zollo Amvam, P. H., and Mathur, S. B. 2004. "Evaluation of Five Essential Oils from Aromatic Plants of Cameroon for Controlling Food Spoilage and Mycotoxin Producing Fungi." Int. J. Food Microb. 94: 329-34.

[15] Gianfagnan, T. J., Carter, C. D., and Sacalis J. N. 1992. "Temperature and Photoperiod Influence Trichome Density and Sesquiterpene Content of Lycopersicon Hirsutum F. Hirsutum." Plant Physiol. 100 (3): 1403-5.

[16] Khanna, R., Johri, J. K., Srivastava, K. M., and Khanna, S. 1991. "Screening for Alternative Biocides amongst Plant Based Essentials Oils." Natl. Acad. Sci. Lett. 14: 3-6.

[17] Tewari, S. N., and Najak, M. 1991. "Activity of Four Plant Leaf Extracts against Three Fungal Pathogens of Rice.” Trop. Agric. 68: 373-5. 